\title{
SEJARAH TRADISI TULIS \\ DALAM MASYARAKAT SASAK LOMBOK
}

\author{
Jamaluddin
}

\section{Abstract}

A great number of classical intellectual treatises, usually called manuscripts, can be found in Lombok, an island in West Nusa Tenggara province. All the manuscripts indicate that writing tradition has been growing in this island since a long time ago. Of many factors influenced the growing of that tradition is trade relationship between Lombok traders and those from other islands. Some significant contributions can be traced through languages ever used in oral communication and in works produced in the community i.e. Sasak, Java, Bali, and Malay, Sanskrit, Arabics. The relationship also contributed to rising intellectual activity and enriching contents of the manuscripts.

This article observes historical sides of the writing tradition by providing historical data, epigraphs and other supporting resources that made the writing tradition exist.

The article tradition in Sasak community is predicted to have been started since the Sasak people recognized writing system, and have developed bundreds of years ago, producing thousands of manuscripts in some different languages, titles and forms. The writing systems used were varied such as old Javanese, Arab, Bali and Bugis. And the languages used were old Java, Java, Bali, Arabic and Malay. This indicates that, long time ago, Sasak people had made contact with people from many parts of this archipelago like Bali, Java, Malay and even Celebes (Bugis).

Keywords: Naskah,Tradisi Tulis, Budaya, Kajian Historis.

MANUSKRIP di Nusantara yang tersebar di seluruh pelosok negeri ini ditulis tidak hanya menggunakan bahasa asing, seperti Arab dan Sansekerta, tetapi juga bahasa-bahasa daerah. Hal ini mengindikasikan terjadinya vernakularisasi (pribumisasi) Islam sehingga memungkinkan bisa dipahami secara lebih mudah oleh masyarakat yang berbeda pada setiap daerah di Indonesia.

Dengan berbagai macam bahasa yang digunakan, di Lombok ditemukan naskah-naskah dalam jumlah yang cukup besar, yang di dalamnya mencakup berbagai informasi penting tentang bermacam bidang kehidupan, seperti sastra, agama, sejarah, hukum, politik, adat-istiadat, farmakologi, prophesies, 
dan lain sebagainya. Naskah-naskah tersebut, dengan memperhatikan luasnya cakupan bidang yang digarap, sangat mungkin tercipta dan berkembang karena banyak faktor yang mendukung. Naskah-naskah tersebut menjadi potret dari peradaban masyarakat Sasak yang telah dicapai pada era kerajaan Islam di Lombok yang menghadirkan gambaran realitas kehidupan masyarakat pada saat naskah tersebut dibuat. Oleh karena itu, tentu sangatlah keliru kalau ada sebagian kalangan yang secara langsung ataupun tidak langsung berpandangan bahwa manuskrip atau naskah yang ditulis pada masa lampau adalah tidak atau kurang bernilai, dengan tanpa didahului penelitian yang cermat. Pandangan demikian dikritik keras oleh Azyumardi Azra dengan menyatakannya sebagai sangat simplistik dan menyesatkan, karena-berdasarkan temuannya ketika meneliti jaringan intelektual ulama Timur Tengah dengan Asia Tenggara melalui naskahnaskah Nusantara-para ulama pemikir dan penulis naskah Islam, paling tidak sejak abad XVII M, telah menghasilkan karya-karya yang menjadi tonggak intelektualisme yang sangat penting bagi Islam Nusantara. ${ }^{1}$

Untuk kasus pernaskahan Sasak, banyaknya manuskrip yang ditemukan di kalangan masyarakat Lombok, tentunya memunculkan beberapa pertanyaan. Misalnya, sejak kapan naskah-naskah atau manuskrip itu mulai ditulis, dan bagaimana latar sosio-kultural masyarakat ketika itu sehingga mereka mampu menulis naskah yang demikian banyaknya. Tulisan ini akan mengungkapkan dan mengkaji data-data sejarah dalam kaitannya dengan pernaskahan dan tradisi tulis masyarakat Sasak.

\section{Sejarah Tradisi Tulis Sasak}

Banyaknya naskah yang ditemukan di Lombok dalam jumlah besar mengindikasikan bahwa tradisi tulis telah berkembang dengan baik sejak masyarakat Sasak mengenal tulisan. Beberapa tulisan (aksara) yang digunakan dalam naskah-naskah di Lombok adalah aksara Jejawen, Arab, Bali, dan beberapa di antaranya (tapi jarang ditemukan) Bugis. ${ }^{2}$ Demikian juga halnya

${ }^{1}$ Azyumardi Azra, Naskah dan Rekonstruksi Sejarah Sosial-Intelektual Nusantara, Makalah disampaikan pada Simposium Internasional Pernaskahan Nusantara VII dan Munas Manasa III, Wisma Syahida Syarif Hidayatullah Jakarta, 26-28 Juli 2004, 2.

${ }^{2}$ Salah satu naskah yang menggunakan aksara Bugis adalah Naskah Bugis, Naskah ini selain beraksara Bugis, bahasa yang digunakan juga Bugis, bahannya kertas, jumlah lempir (halaman) 38, dengan kondisi masih baik. Ditemukan di dusun Penjor, desa Gondang kecamatan Gangga dan sampai sekarang ini masih dikoleksi oleh masyarakat setempat. 
dengan bahasa, paling tidak ada tujuh macam bahasa yang sering digunakan, yaitu Jawa Kuno, Sansekerta, Jawa, Sasak, Bali, Arab, dan Melayu.

Tidak banyak tulisan yang menjelaskan tentang kapan penulisan naskahnaskah dilakukan, lebih-lebih banyak naskah di Lombok jarang yang menggunakan kolofon. ${ }^{3}$ Kalaupun ada, sering tidak lengkap, seperti informasi berikut ini, "naskah ini selesai ditulis pada tanggal 5 hari Jum'at", tanpa menyebut tahun. Selain karena alasan tersebut, banyak naskah yang kemudian ternyata sudah dalam bentuk salinan yang kesekian kalinya. Jadi, kalaupun ada yang menyebut angka tahun, tidak dapat dijadikan standar dalam menentukan kapan naskah tersebut pertama kali ditulis. Dalam kajian naskah atau ilmu filologi (Tabqî́q al-Nushûsh), dikenal metode stema, ${ }^{4}$ yaitu metode yang digunakan untuk menemukan naskah asli atau menemukan silsilah suatu naskah. Namun, metode tersebut tidak dapat memberikan jawaban terhadap kepastian kapan tradisi tulis masyarakat Sasak itu dimulai. Untuk itu, penelusurannya dapat dilakukan melalui pendekatan historis.

Memperhatikan aksara-aksara dan bahasa yang digunakan, maka kuat dugaan bahwa tradisi tulis telah dimulai sejak adanya hubungan dengan banyak negeri atau daerah di luar Lombok. Sudah barang tentu kaitannya dengan hal ini adalah daerah yang telah mengenal budaya tulis-menulis; karenanya, hubungan Lombok dengan negeri lain di luar konteks itu tidak akan dibicarakan.

${ }^{3}$ Kegunaan kolofon yang pertama adalah memberi data tentang identitas karya yang terkandung dalam naskah (nama penulis, tempat, dan waktu penulisan) dan kedua, untuk menyajikan informasi tentang salinan naskah. Kolofon biasanya terdapat pada penutup naskah atau ada juga yang di awal. Lihat, Henri Chambert-Loir, "Kolofon", Makalah disampaikan pada Simposium Internasional Pernaskahan Nusantara VII dan Munas Manasa III, Wisma Syahida Syarif Hidayatullah Jakarta, 26-28 Juli 2004, 3.

${ }^{4}$ Metode ini dikembangkan oleh Lackman pada tahun 1830-an. Beberapa nama yang kemudian mengembangkan metode ini J. J. Rass, dalam Hikayat Banjar (1968). Ketika meneliti Hikayat Banjar, ia berhasil mengumpulkan 23 Naskah yang tersebar di berbagai tempat. Rass membandingkan semua naskah kata demi kata dan episode demi episode. Ia berhasil menemukan perbedaan yang besar dalam isi cerita sehingga menghasilkan dua versi. Jelasnya, lihat J. J. Rass, Hikayat Banjar dan Kotawaringin: A study in Malay Historiography (Bibliotheca I. The Hague: Martinus Nijhoff, 1968), 78-80. Panuti Sudjiman juga melakukan hal yang sama ketika meneliti naskah Adat Raja-Raja Melayu, lihat Panuti Sudjiman, Adat Raja-Raja Melayu (Jakarta: Penerbit Universitas Indonesia, 1981). Untuk jelasnya langkah-langkah tersebut, lihat Panuti Sudjiman, Filologi Melayu (Jakarta: Dunia Pustaka Jaya, 1995), 86-92. 
Dari segi bahasa, pengaruh Jawa dan Bali sepertinya cukup kuat. Namun, untuk yang pertama, beberapa sumber menyebutkan bahwa itulah asal dari nenek moyang suku bangsa Sasak, sehingga pengaruh Jawa dalam masyarakat Sasak sangat kental terlihat. Contoh kecil saja, dapat dilihat pada beberapa nama desa di Lombok, seperti Surabaya, Gerisak (Geresik), Mataram, Kediri, dan Wanasaba. Demikian juga, beberapa raja awal yang memerintah di Lombok juga berasal dari Jawa, seperti Ratu Mas Panji, raja di kerajaan Sasak, ${ }^{5}$ diperkirakan letaknya di Blongas sekarang (Kecamatan Gerung).

Beberapa bukti lain tentang hubungan dan sekaligus menguatkan keberadaan kerajaan tersebut adalah ditemukannya kentongan perunggu di Pujangan Tabanan, yang menginformasikan tentang kemenangan kerajaan Bali atas negeri Sasak, yang diperkirakan dibuat setelah anak Wungsu (abad XI M). Selain itu diperkuat lagi oleh prasasti Lutungan yang menyebutkan tentang pembelian 30 ekor kerbau oleh anak Wungsu dari Gurun. ${ }^{6}$ Beberapa prasasti lain, seperti prasasti Belanjong, turut memperkuat tesis tentang itu. ${ }^{7}$

Memperhatikan hubungan Lombok dengan negeri-negeri lain, maka tampak jelas bahwa pada masa silam, sekitar abad IX M, Lombok telah menjalin hubungan dengan daerah luar. Maka, wajar kalau dari sisi bahasa terlihat pengaruhnya yang sangat kental dalam masyarakat Sasak. Demikian juga dalam tradisi tulis. Dengan ditemukannya beberapa prasasti tersebut dapat diketahui bahwa negeri Bali, dalam hal ini yang menjalin hubungan dengan Lombok, telah mengenal tradisi tulis-menulis. Dengan demikian, interaksi antara Bali dan Lombok, paling tidak telah memperkenalkan tulisan kepada masyarakat Lombok. Sementara hubungan antara Jawa dan Lombok pada abad IX atau X M belum ditemukan data tertulis berupa prasasti seperti yang ada di Bali. Namun, kuat dugaan Jawa memiliki peran yang cukup krusial; hal ini dapat dilihat pada penggunaan Bahasa Jawa Kuno, Sansekerta, pada masa-masa itu.

Letak pulau Lombok pada posisi yang sangat strategis dalam jalur perdagangan di kepulauan Nusantara menjadikannya sebagai penghubung

${ }^{5}$ Lalu Wacana, Sejarah Nusa Tenggara Barat (Mataram: Departemen Pendidikan dan Kebudayaan, 2002), 20.

${ }^{6}$ Menurut R. Goris yang dimaksud Gurun adalah Pulau Lombok (Gerung). Lihat Marwati Djonet Poesponegoro dan Nugroho Notosusanto, Sejarah Nasional Indonesia (Jakarta: Balai Pustaka, 1993), 353.

7Ibid., 293. Lihat juga Jamaluddin, Islam Sasak: Sejarah Sosial dan Keagamaan di Lombok (Abad XVI-XIX), Tesis (Jakarta: UIN Syarif Hidayatullah Jakarta, 2004), 59. 
bagi perdagangan antara timur dan barat. Keterlibatan Lombok dalam jalur perdagangan tidak dapat dianggap kecil artinya bagi perkembangan perdagangan regional dan internasional. Pada awal-awal dibukanya jalur perdagangan di sepanjang pesisir kepulauan Nusantara di Jawa muncul kerajaan maritim Hindu Tarumanegara, tepatnya di Jawa Barat yang menguasai jalur perdagangan utara pulau Jawa sampai Sulawesi hingga abad VII M. Kemudian jalur perdagangan pindah ke Selat Malaka di bawah hegemoni kerajaan maritim Hindu-Sriwijaya, sampai abad XI M. Sejak abad XII M jalur perdagangan di sepanjang pantai utara pulau Jawa ke timur sampai di ujung kepulauan Nusantara kembali ramai seiring dengan munculnya adikuasa baru kerajaan agraris-maritim Hindu Budha Majapahit.

Hubungan Lombok dengan kerajaan-kerajaan yang ada di Nusantara sebelum era Majapahit sifatnya lebih sebagai hubungan dagang. Perubahan zona perdagangan juga berpengaruh terhadap hubungan tersebut. Hubungan dagang itu dapat diketahui dari sumber-sumber historiografi tradisional Lombok. Diungkapkan bahwa kerajaan Lombok telah menjalin hubungan diplomatik dengan raja Palembang (Sriwijaya), ${ }^{8}$ juga dengan Sulawesi (Wong Bojo). ${ }^{9}$ Palembang yang merupakan ibukota Sriwijaya telah menjadi pusat pengajaran agama Budha sehingga orang-orang dari daratan Cina yang akan belajar agama Budha di India dianjurkan untuk menetap setahun di Sriwijaya untuk belajar bahasa Sansekerta. ${ }^{10}$ Berlangsungnya hubungan Lombok dengan Palembang, yang kala itu telah menjadi pusat pengajaran agama Budha dengan bahasa Sansekerta, memperkuat dugaan bahwa penggunaan bahasa Sansekerta di Lombok pertama kali berawal dari pengaruh kuat kota pusat Kerajaan Sriwijaya itu.

Penggunaan bahasa Jawa Kuno telah dimulai sejak adanya kontak dagang antara orang Sasak dengan orang Jawa. Lebih dari itu bisa jadi bahasa Jawa

${ }^{8}$ Kerajaan Lombok memberikan perlindungan kepada para pedagang yang datang dari Palembang (Sriwijaya). Ketika terjadi konflik antara Patih Brangbantun dengan pedagang dari Palembang-Patih Brangbantun tidak mau membayar hutangnya kepada pedagang dari Palembang-persoalan itu disampaikan kepada raja Prabu Nyakrawati di Lombok Wanagiri. Baginda mengizinkan supaya Palembang memerangi Brangbantun karena dianggap merusak hubungan antara Raja Lombok dengan Raja Sriwijaya. Patih Brangbantun dapat dikalahkan dan melarikan diri ke Monggok. Lihat, Ibid., 52-3, 75.

'Lalu Wacana, Babad Lombok (Jakarta: Departemen Pendidikan dan Kebudayaan, 1974), 58.

${ }^{10}$ Ann Kumar dan John H. McGlynn, Illuminations: The Writing Traditions of Indonesia (New York: Weatherhill Inc. 1996), XVI. 
telah menjadi bahasa pengantar para pedagang ketika itu. Bahasa Jawa Kuno termasuk rumpun bahasa yang dikenal sebagai bahasa-bahasa Nusantara dan merupakan suatu subbagian dari kelompok linguistik Austronesia. Di Nusantara terdapat paling tidak 250 macam bahasa. ${ }^{11}$ Untuk tulisan berbahasa Sansekerta ditemukan pada sebuah prasasti tertua yang menunjukkan angka tahun 732 M. ${ }^{12}$ Prasasti yang menggunakan huruf Pallawa akhir itu ditemukan di Gunung Wukir Canggal, Magelang. Sedangkan bahasa Jawa Kuno pada prasasti tertua ditemukan di Sukabumi menunjukkan angka tahun 804 M. ${ }^{13}$ Untuk bahasa Melayu, karya satra tulis tertua, berasal dari sekitar tahun 1600 M, ${ }^{14}$ baru kemudian bahasa Aceh Batak, Minangkabau, Sunda, Bugis, Bali, dan Sasak. Di antara bahasa-bahasa itu, bahasa Jawa menduduki tempat teristimewa karena karya-karya berasal dari abad IX dan X M. ${ }^{15}$ Dengan kata lain, Jawa Kuno telah dipakai pada karya-karya tertua itu. ${ }^{16}$

Sebagaimana yang dijelaskan di atas, berdasarkan beberapa bukti yang dikemukakan, Lombok telah terlibat dalam kontak dagang dan bahkan politik dengan pusat-pusat daerah Jawa dan Bali yang pada masa itu sudah berkembang tradisi tulis. Oleh karena itu, kuat dugaan bahwa bahasa-bahasa tersebut dalam waktu yang bersamaan juga mengalami perkembangan di Lombok.

Banyak karya tulis yang belum ditemukan, selain dari yang telah tersimpan di museum-museum. Namun, beberapa sumber dapat dipergunakan untuk melacak sejak kapan tradisi tulis itu dimulai, salah

\footnotetext{
11P. J. Zoetmulder, Kalangwan (Jakarta: Jambatan,1985), 8.

${ }^{12}$ Louis-Charles Damais, Epigrafi dan Sejarah Nusantara (Jakarta: Ecole Francaise d'Extreme-Orien, 1995), 9.

13Zoetmulder, Kalangwan, 3.

${ }^{14}$ Menurut perkiraan Brakel, di Melayu penerjemahan naskah telah dilakukan lebih awal dari yang diperkirakan, yaitu abad XIV M, misalnya Hikayat Muhammad Hanafiyah. Lihat L. Brakel, The Hikayat Muhammad Hanafiyyah: A Medieval-Malay Romance (The Hague, Nijhoff: KITLV, 1975) 56-7.

${ }^{15} \mathrm{Di} J a w a$ tradisi tulis-menulis bermula pada masa Sri Darmawangsa Teguh Anantawikrama yang terkenal dengan upayanya menjawakan Biyasamata, artinya membahasajawakan ajaran-ajaran Baghawan Byasa. Darmawangsa memerintah kira-kira Tahun 991-1017. Lihat Achdiati, Peradaban Manusia Zaman Peradaban Kuna (Jakarta: Gita Karya, t.t.), 10-2.

16Zoetmulder, Kalangwan, 4.
} 
satunya adalah informasi yang terdapat dalam Babad Nagarakertagama ${ }^{17}$ yang di dalamnya disebutkan nama Lombok dengan Lombok Mirah. Untuk menguatkan pendapat tersebut, di Lombok juga ditemukan sebuah manuskrip ${ }^{18}$ yang mengabadikan kedatangan Majapahit ke Lombok, yang disimbolkan dengan kedatangan seorang satria yang bernama Lumendang Sari asal Waringin Sungsang Majapahit, yang datang bersama-sama dengan Gajah Mada. Dalam manuskrip tersebut juga disebutkan bahwa Majapahit mengambil putri-putri kerajaan di Lombok untuk dinikahkan dengan keluarga kerajaan Majapahit. Menurut kalangan sejarawan, kedatangan Majapahit pertama kali melalui ekspedisi yang dipimpin oleh Mpu Nala sekitar tahun $1343 \mathrm{M}$, baru kemudian kedatangan Gajah Mada sepuluh tahun kemudian, sekitar tahun 1353 M. ${ }^{19}$

Dengan demikian, dapat dikatakan bahwa penguatan pengaruh Jawa dalam masyarakat Sasak terjadi setelah adanya hubungan politik dengan Majapahit. Kehadiran pembesar Majapahit ke Lombok adalah untuk tujuan penguasaan wilayah timur Indonesia. Ekspedisi pertama di bawah pimpinan Patih Nala (Mpu Nala), dan ekpedisi kedua langsung dipimpin oleh Gajah Mada. Mpu Nala kemudian menetap di Lombok yang kemudian menurunkan raja-raja di Lombok. Deneq Mas Muncul adalah putra bungsu Mpu Nala yang menjadi raja di Bayan. Deneq Mas Muncul menurunkan

${ }^{17}$ Babad Nagarakertagama adalah sebuah babad yang ditulis oleh Mpu Prapanca, yang menjelaskan hubungan Majapahit dengan semua wilayah yang ada di Nusantara. Babad ini ditemukan di Lombok pada waktu penyerbuan Belanda terhadap kerajaan Bali di Lombok pada tahun, 1894 M. Babad ini telah dibawa oleh pihak Belanda ke Leiden dan atas permintaan pemerintah RI babad tersebut dikembalikan lagi ke Indonesia. Naskah tersebut berbahasa Jawa Kuno, kemudian diterbitkan dalam huruf Bali dan Bahasa Belanda oleh Brandes (1902), tetapi hanya sebagian, disusul kemudian upaya penerjemahan oleh Kern tahun 1905-1914 yang dilengkapi dengan komentar-komentarnya. Baru pada tahun 1919, Krom menerbitkan utuh isi lontar Nagarakertagama. Krom juga melengkapinya dengan catatan historis. Naskah Nagarakertagama ini diterjemahkan dalam Bahasa Indonesia oleh Slamet Mulyana dan disertai dengan tafsir sejarahnya. Menyusul kemudian, Th. Pigeud yang menerjemahkan naskah tersebut ke dalam Bahasa Inggris. Tentang Babad ini lebih jelasnya lihat C. C. Berg, "Gambaran Jawa Pada Masa Lalu" dalam Historiografi Indonesia: Sebuah Pengantar, ed. Soedjatmoko, et.al. (Jakarta: Gramedia Pustaka Utama, 1995), 85-90.

${ }^{18}$ Manuskrip ini disebut Bencingah Punan ditulis pada lempengan perunggu, dengan menggunakan bahasa Jawa Kuno. Lengkapnya isi naskah tersebut dan sudah ditransliterasikan, lihat Team Penyusun Monografi Daerah NTB, Monografi Daerah Nusa Tenggara Barat (Proyek pengembangan Media Kebudayaan Direktorat Jenderal Kebudayaan Departemen Pendidikan dan Kebudayaan RI, 1977), 12.

${ }^{19}$ Lalu Jelenga, Keris di Lombok (Mataram: Yayasan Pusaka Selaparang, t.t.), 16. 
Deneq Mas Korabela, kemudian Deneq Mas Laki Singia. ${ }^{20}$ Tentang hal ini, dalam Babad Lombok disebutkan kerajaan Bayan adalah kerajaan besar yang didirikan oleh putra Sri Baginda Majapahit. ${ }^{21}$ Dengan kehadiran orang-orang Majapahit di Lombok, yang kemudian membangun kerajaan bersama pemuka atau tokoh-tokoh Bayan, menjadikan bahasa Jawa sangat berpengaruh dalam masyarakat Sasak.

Majapahit telah lama mengenal tradisi tulis. Tradisi tulis di kalangan masyarakat Sasak diduga kuat dimulai sejak Majapahit menancapkan kekuasaannya di Lombok. Karena belum ditemukan bukti lain yang lebih tua dari manuskrip di atas, maka standar untuk menetapkan tahun mulainya tradisi tulis dalam masyarakat Sasak adalah tahun 1353 M, pada saat manuskrip tersebut ditulis.

Pengaruh Jawa sesudah keruntuhan Majapahit diwakili oleh kerajaankerajaan Islam di Jawa. Kerajaan Islam Jawa menancapkan pengaruhnya ke wilayah timur (Lombok) ini berakhir sekitar abad XVII M, seiring dengan semakin kuatnya dominasi Eropa terhadap Jawa. Secara bersamaan, pengaruh Melayu berlanjut sampai abad XIX M sehingga aksara Arab ataupun Arab Melayu mulai dikenal oleh masyarakat Sasak setelah terjadinya islamisasi di Lombok.

Ditemukannya banyak naskah Melayu di Lombok mengindikasikan bahwa Melayu juga memberikan pengaruh yang tidak kecil dalam hal tradisi tulis. Beberapa naskah ditemukan di Lombok yang merupakan naskah Melayu, antara lain Nur Mubammad, Nabi Mubammad, Nabi Haparas/Aparas, Nabi Ibrabim, Yazid, Malaikat Jibril, dan Nabi Yusuf. Naskah-naskah tersebut telah diterjemahkan pertama kali di Melayu, kemudian tersebar ke berbagai wilayah di Nusantara. Di Lombok naskah ini menggunakan huruf Jejawen (tulisan Sasak), sedangkan bahasa yang digunakan adalah bahasa Sasak, sebagian bahasa Jawa dan Melayu. Naskah yang menggunakan bahasa Melayu pada umumnya menggunakan tulisan Arab Melayu (huruf Jawi).

Naskah-naskah Melayu telah diterjemahkan atau disalin secara besarbesaran oleh masyarakat Sasak, misalnya naskah Nabi Haparas/Aparas yang memiliki sekitar empat puluhan naskah salinan di Museum Negeri NTB dan naskah Nabi Yusuf yang berjumlah sekitar tiga puluh tujuh naskah salinan. Aktivitas tradisi penulisan/penyalinan naskah pada masyarakat Sasak terus berlanjut hingga abad XX M.

\footnotetext{
${ }^{20} \mathrm{Ibid}$.

${ }^{21}$ Lalu Wacana, Babad...,67.
} 
Naskah-naskah berbahasa dan beraksara Bali berkembang di kalangan suku Bali yang mendiami pulau Lombok di bagian Barat, sejak terjadi penaklukan oleh penguasa Bali atas kerajaan Islam di Lombok sekitar awal abad XVII M, atau boleh jadi lebih awal dari perkiraan. Beberapa sumber Bali menyebutkan orang-orang Bali telah datang ke Lombok jauh sebelum invasi itu dilakukan, pada awal abad XVII M, yang membuat perkampungan di wilayah Barat pulau Lombok. ${ }^{22}$

\section{Perkembangan Tradisi Tulis dalam Masyarakat Sasak}

Naskah-naskah kuno ${ }^{23}$ yang ada pada umumnya dapat diselamatkan oleh lembaga pemerintahan maupun swasta, antara lain seperti yang ada di Museum Nasional, kemudian dipindahkan ke Perpustakaan Nasional. Pada masa sekarang ini sebagian dari naskah itu telah dimikrofilmkan. Masih banyak naskah yang ada di tangan masyarakat yang kebanyakan dari mereka tidak memahami tentang perawatan naskah-naskah tersebut. Oleh karena itu, semua pihak dituntut untuk memiliki rasa tanggung jawab terhadap keselamatan naskah-naskah tersebut.

Demikian juga halnya dengan naskah-naskah atau manuskrip yang berasal dari Lombok, beberapa di antaranya yang dapat diselamatkan sekarang ini masih ada di Museum Negeri Nusa Tenggara Barat. Semua yang ada di museum tersebut belum ada yang dimikrofilmkan, kecuali beberapa dari manuskrip yang dibawa ke Jakarta, atau yang dikembalikan dari pemerintahan Belanda. Selain dalam bentuk mikrofilm, naskah-naskah itu juga sudah ada yang difaksimilikan sehingga untuk sebuah penelitian naskah akan lebih gampang dilakukan dengan tanpa ada kekhawatiran akan terjadi kerusakan pada naskah asli.

${ }^{22}$ Lihat Ide Anak Agung Gde Agung, Bali Pada Abad XIX: Perjuangan Rakyat dan RajaRaja Menentang Kolonialisme Belanda 1808-1908 (Yogyakarta: Gajah Mada University Press, 1989), 102-3.

${ }^{23}$ Sebuah naskah dapat disebut sebagai naskah kuno apabila naskah itu telah berumur paling kurang 50 tahun. Hal itu didasarkan pada monumen ordonansi STBL No. 238 Tahun 1893 yang menjelaskan bahwa naskah dapat disebut sebagai naskah kuno bila telah berumur paling kurang 50 tahun. Lihat Tashadi, "Pembinaan Penelitian dan Pelestarian Naskah" Makalah dalam kongres bahasa Jawa di Semarang 1991, 5; Lihat juga Tuti Munawar, "Khazanah Naskah Nusantara" dalam Tradisi Tulis Nusantara: Kumpulan Makalah Simposium Tradisi Tulis Indonesia 4-6 Juni 1996 (Jakarta: Masyarakat Pernaskahan Nusantara, 1997), 43. 
Perawatan naskah menjadi sangat urgen bagi pelestarian warisan-warisan kuno. Ada beberapa faktor penyebab yang mungkin secara tidak disadari mengancam eksistensi naskah; faktor suhu sekalipun sangat menentukan tingkat kelangsungan dari manuskrip-manuskrip itu. Oleh karena itu, dibutuhkan pengetahuan khusus terhadap perawatan manuskrip atau naskah.

Banyak sekali naskah sudah tidak dapat digunakan lagi, selain karena umur naskah yang sudah tua, juga karena kondisinya yang tidak memungkinkan untuk diakses. Kondisi demikian terjadi biasanya karena ketidakpahaman para kolektor terhadap perawatan naskah. Jadi, sebelum terjadinya kerusakan lebih awal dilakukan penggandaan atau penyalinan naskah. Tradisi semacam ini telah berkembang sejak dahulu hingga awalawal abad XX M.

Tradisi tulis dalam masyarakat Sasak diperkirakan telah dimulai sebelum kedatangan Islam, yakni pada masa Hindu-Budha, baru kemudian mengalami perkembangannya setelah datangnya Islam. Tidak ditemukan tulisan-tulisan sebagai karya masyarakat Lombok sebelum datangnya Islam pada abad XVI M. Hal itu bukan berarti bahwa mereka samasekali tidak memiliki karya. Boleh jadi sebelum abad itu tulisan-tulisan mereka sudah ada, tetapi tulisan-tulisan tersebut tidak sampai kepada kita, atau karya-karya mereka telah ditulis ulang pada era kerajaan Islam. Memang sulit dilacak, tetapi beberapa indikasi mengarah pada anggapan tersebut, yaitu dengan ditemukan beberapa karya intelektual yang isi ceritanya diislamkan ${ }^{24}$, misalnya cerita Ramayana. ${ }^{25}$ Di masyarakat Sasak berkembang cerita dengan tokoh Dewi Anjani. ${ }^{26}$ Cerita ini sangat mirip dengan cerita Ramayana. ${ }^{27}$

${ }^{24}$ Istilah islamisasi naskah dalam hal ini dimaksudkan sebagai kegiatan penulisan ulang naskah-naskah (pra-Islam) sesudah kedatangan Islam yang penulisannya mengalami perubahan, misalnya pada perubahan nama tokoh-tokohnya atau sebagian cerita-ceritanya mengalami perubahan. Hampir pada sebagian besar naskah yang ditulis pada era Islam diawali dengan basmalah atau pujian kepada Allah dan Rasul.

${ }^{25}$ Cerita Ramayana adalah cerita yang berasal dari India (tradisi Hindu) yang tokohtokohnya banyak dijadikan sebagai sumber cerita dalam pewayangan. Dalam penyebaran ke Asia Tenggara, khususnya Indonesia, cerita-cerita asal India ini mengalami proses pengindonesiaan sehingga terjadilah pengubahan tokoh-tokoh dan cerita-cerita karena adanya penyesuaian dengan pola kehidupan Indonesia. Dewaki Kramadibrata-Nugarjito, Cerita Wayang Melayu Palembang: Sebuah Pengantar dalam Jati Diri yang Terlupakan: NaskahNaskah Palembang (Jakarta: Yayasan Naskah Nusantara, 2004), 145.

${ }^{26}$ Dewi Anjani adalah tokoh yang dalam cerita-cerita rakyat sering dimunculkan sebagai orang yang memiliki kesaktian luar biasa. Karena kesaktiannya, Dewi Anjani diangkat 
Kehadiran Islam di Lombok memberikan nuansa baru bagi perkembangan tradisi tulis di masyarakat Sasak. Karya-karya besar yang dihasilkan pada umumnya telah dimulai dari abad XVI M di pusat-pusat kota kerajaan dan di kota-kota muslim lainnya.

Berkembangnya budaya tulis dalam masyarakat Sasak tidak dapat dilepaskan dari beberapa faktor ${ }^{28}$ yang mempengaruhinya. Pertama, kehadiran Islam dengan berbagai ragam ajarannya, Islam adalah agama yang kaya akan ajaran-ajaran agama dan budaya yang tidak mungkin dapat ditransformasikan hanya dengan tradisi lisan, ditambah lagi keharusan untuk disampaikan dan disebarkan kepada masyarakat. Naskah-naskah yang paling banyak ditulis adalah tasawuf. ${ }^{29}$ Naskah-naskah tersebut menjelaskan perjalanan spiritual manusia menuju Tuhannya, dengan bahasa-bahasa yang sangat sederhana dalam bentuk cerita-cerita, tetapi di dalamnya terkandung makna filosofis yang sangat tinggi. Selain itu, juga terdapat tentang doa-doa, fiqh, dan ajaranajaran dasar Islam.

Kedua, adanya dukungan yang kuat dari kalangan Istana. Istana memfasilitasi segala kegiatan yang terkait dengan penulisan karya intelektual muslim ketika itu. Karya-karya mereka banyak yang bertemakan sejarah, politik, dan budaya yang banyak ditulis di pusat-pusat kerajaan Islam pada waktu itu, misalnya, Babad Lombok, yang terakhir ditemukan bertahun 1301 $\mathrm{H}$ atau 1883-1884 M. Babad ini ditulis untuk pertama kalinya jauh lebih awal dari tahun yang disebutkan, yaitu pada masa kejayaan kerajaan Islam. Jadi, kemungkinan penulis terakhir melakukan salinan-salinan, yang kemudian menambah data-data yang belum ada dalam Babad tersebut. Babad Lombok terdiri dari dua bagian: bagian pertama, menjelaskan asal usul Lombok,

menjadi raja jin. Sebagai seorang raja, dia memiliki kewenangan untuk mengatur kehidupan jin. Lihat Team, Monografi..., 9.

${ }^{27}$ Jelasnya lihat V. J. Herman et.al., Bunga Rampai Kutipan Naskah Lama dan Aspek Pengetabuannya (Mataram: Departemen Pendidikan dan Kebudayaan Direktorat Jenderal Kebudayaan Museum Negeri Nusa Tenggara Barat, 1990/1991), 8-9.

${ }^{28}$ Jamaluddin, Islam..., 168-9.

${ }^{29}$ Karya-karya tasawuf biasanya disajikan dalam bentuk cerita-cerita. Salah satu karya tasawuf yang merupakan karya masyarakat Sasak klasik adalah Puspakrama. Naskah ini paling tidak terdapat lebih dari 193 naskah, lihat Th. C. Dick Van der Meij, Puspakrame: A Javanese Romance From Lombok (Leiden: CNWS, 2002), bab III. Dalam tulisan terbarunya Dick menyebutkan bahkan lebih banyak dari jumlah yang diperikan sebelumnya, lihat Th. C. Dick Van der Meij, Puspakrama Dibaca dari Segi Kebudayaan Wetu Telu di Lombok, Makalah disampaikan pada Simposium Internasional Pernaskahan Nusantara VII dan Munas Manasa III, Wisma Syahida Syarif Hidayatullah Jakarta, 26-28 Juli 2004, 2. 
penduduk Lombok, dan raja-raja Lombok, dan masa-masa awal kerajaan Islam di Lombok; bagian kedua banyak menjelaskan tentang perkembangan politik kerajaan Islam di Lombok.

Selain itu, ada juga Babad Selaparang, Babad Suwung, Babad Praya, dan Babad Sakra, yang semuanya merupakan sejarah politik di Lombok. Selain tentang sejarah politik, yang paling penting adalah aturan-aturan yang harus ditegakkan oleh negara dalam bentuk kitab undang-undang. Kitab tersebut diberi nama Kotaragama. ${ }^{30}$ Di dalamnya berisi aturan-aturan yang mengatur kehidupan bermasyarakat yang harus ditaati oleh semua pihak, baik raja sebagai pemimpin negara maupun rakyat sebagai abdi negara. Di pusat kerajaan juga banyak para penulis yang menulis tentang agama dan lain sebagainya.

Faktor yang ketiga adalah faktor budaya. Di kalangan masyarakat Sasak, membaca naskah-naskah lontar sudah menjadi tradisi dan dikenal luas oleh masyarakat Sasak. Tradisi membaca naskah lontar dalam masyarakat sasak disebut pepaosan. Naskah-naskah dibaca dengan menggunakan lagu-lagu (ditembangkan). Ada enam tembang yang cukup populer dikenal di kalangan masyarakat Sasak, yaitu Durma, Sinom, Smarandana, Pangkur, Dangdang (Dangdang Gula), dan Mas Kumambang. Namun, dalam membaca kitab Serat Menak (Jawa) dikenal pula tembang-tembang, seperti Kinanti, Girisa, dan Pucung. ${ }^{31}$

Tradisi pembacaan hikayat Melayu (Jawi) di Sasak dikenal dengan istilah bakayat. Yang dibaca adalah hikayat-hikayat, seperti hikayat nabi-nabi (Qishash al Anbiyâ), Qamaruzzaman, Nabi Bercukur, dan Ali Hanafiyah (Yazid). Pembacaan hikayat ini yang disertai dengan lagu (Sasak: kayat), sangat mirip dengan lagu hikayat yang berkembang di Melayu. Pembacaan hikayat ini juga membutuhkan penerjemah dan pendukung. Pembacaan hikayat Melayu dalam bentuk sya'ir disebut nya'ir. Kitab sya'ir yang terkenal di antaranya adalah Siti Zubaidah, Saer Kubur, dan Qamaruzzaman. ${ }^{32}$ Tradisi pembacaan naskah, yaitu pepaosan, bakayat, dan nya'er, merupakan kegiatan yang erat kaitannya dengan upacara adat dan keagamaan. Pembacaan naskah-naskah

${ }^{30}$ Jelasnya lihat Lalu Gde Suparman et.al., Pengungkapan Nilai Budaya Naskah Kuno Kotaragama (Mataram: Departemen Pendidikan dan Kebudayaan Direktorat Jendral Kebudayaan Museum Negeri Propinsi NTB, 1995/1996). Aslinya Lontar Kotaragama menggunakan huruf Jejawen (tulisan Sasak) dengan bahasa Kawi. Angka tahun penulisan tidak ada.

${ }^{31}$ Herman et.al., Bunga..., 10.

32Ibid., 11. 
tersebut biasanya diadakan pada setiap malam Jum'at atau pada acara-acara, seperti pernikahan atau khitanan anak yang diadakan pada malam harinya.

Di samping itu, ada juga naskah yang dibacakan dengan tujuan pengobatan (sympatetic-magic). Misalnya Kawitan Selandir (lontar) dibacakan untuk anak yang belum dapat berjalan. Indar Jaya (lontar) dibacakan untuk anak yang sulit berbicara. Indrabangsawan (Jawi) untuk anak yang dungu dan lainnya yang kadang hanya berbentuk kepercayaan satu kelompok masyarakat atau komunitas tertentu. ${ }^{33}$

Pewayangan sebagai khazanah budaya Sasak juga memberi andil yang tidak kecil bagi pesatnya perkembangan tradisi tulis di Lombok. Cerita-cerita dalam pewayangan ditulis dalam naskah-naskah. Selain untuk hiburan, wayang menjadi media yang sangat efektif dalam pengembangan dakwah Islam. Semua cerita-cerita yang ditampilkan oleh wayang Sasak pada dasarnya mengambil cerita Menak ${ }^{34}$ yang sumber ceritanya berasal dari cerita Amir Hamzah, ${ }^{35}$ paman Rasulullah saw. Cerita-cerita berasal dari Persia (Iran) yang masuk ke Indonesia melaui tanah Melayu, kemudian tersebar ke Jawa dan Lombok ${ }^{36}$

Demikian pentingnya naskah-naskah dalam kehidupan masyarakat Sasak, tidaklah mengherankan kalau hampir pada setiap kampung dapat ditemukan naskah-naskah. Pada umumnya naskah-naskah yang banyak tersebar di masyarakat adalah naskah-naskah yang ada hubungannya dengan upacaraupacara atau kegiatan-kegiatan di masyarakat.

Secara umum naskah-naskah yang berkembang di masyarakat Sasak banyak yang tidak diketahui penulisnya karena hampir pada semua naskahnaskah jarang ditemukan nama-nama penulisnya. Ada dua macam jenis

${ }^{33}$ Ibid.

${ }^{34}$ Serat Menak yang ada di Jawa berbeda dengan Serat Menak yang ada di Lombok, Serat Menak yang ada di Jawa ditulis dengan urutan sampai tujuh jilid. Sementara cerita Serat Menak yang ada di Lombok ditulis sesuai dengan kawiannya (fragmennya) sehingga ditemukan berbagai judul, seperti Selandir, Dewi Rengganis, Bidara Kawitan, Gendit Birayung, Bangbari, dan sebagainya.

${ }^{35}$ Dalam cerita pewayangan Amir Hamzah diberikan berbagai gelar, seperti Wong Menak (tata kehidupan yang menyenangkan), Jayengrana (kuat di medan atau arena), Jayeng Laga (kuat di medan laga), Jayeng Tinon (sebagai orang yang memiliki visi dan misi untuk masa yang akan datang), Jayeng Palugon atau Jayeng Palupi (kuat memakai senjata berat), Jayeng Murti (dapat mengalahkan semua kesaktian), Khamidil Alam (gelar terakhir setelah kawin dengan putri Roma yang bernama Hasnaningsih).

${ }^{36}$ Alit Widiastuti dan M. Tarfi, Wayang Sasak (Mataram: Departemen Pendidikan dan Kebudayaan Bagian Proyek Pengembangan Permuseuman Nusa Tenggara Barat, 1987), 8. 
naskah yang berkembang di masyarakat Sasak, yaitu naskah yang ditulis dengan huruf Jejawen dan naskah yang ditulis dengan menggunakan huruf Jawi (Arab Melayu). Naskah-naskah yang ditulis dengan huruf Jejawan bermacam-macam bentuk: ada yang berbentuk salinan, seperti Jatiswara, Dalang Jati, dan Rengganis; ada yang berbentuk tulisan (dari cerita oral ke tulisan), seperti Doyan Neda, Cupak Gerantang, dan Lobangkara; dan ada yang berbentuk saduran, seperti Tapel Adam, Nabi Yusuf, Nabi Ibrabim, Mi'raj Nabi, dan cerita-cerita Menak. Cerita yang disadur dari cerita Menak (Jawa) terdapat berbagai judul, antara lain Banyurung, Kendit Birayung, Kabar Sundari, Gentur Bumi, Pedang Kemkem, dan sebagainya. Sedangkan naskah berbentuk karangan, seperti Silsilah Batu Dendeng, Silsilah Rembitan, Babad Sakra, Babad Praya, Babad Pringgabaya, Babad Selaparang, Pengeling-eling, Mantra, Obat-obat tradisional, dan sebagainya. ${ }^{37}$

Karya-karya historiografi klasik di pulau Lombok yang berbentuk saduran banyak ditemukan. Karya-karya saduran tersebut babonnya ada yang yang berhuruf Jawi (Arab Melayu) dan ada pula yang berhuruf Jawa. Ceritacerita tersebut kemudian dialihkan dengan menggunakan huruf Jejawen. Adapun bahasa yang dipakai adalah bahasa Kawi atau bahasa Sasak serta pada umumnya ditulis di atas daun lontar. Dalam proses penyadurannya sering dilakukan tidak secara utuh, ada yang judulnya yang tetap dan ada pula yang berubah. Bahkan isi sering mengalami pengurangan atau penambahan disesuaikan dengan kondisi masyarakat tempat penyaduran itu dilakukan.

Menyikapi persoalan semacam itu, van Ronkel memberikan sebuah solusi bahwa kalau ada naskah yang ada hubungannya dengan agama Islam, maka naskah Melayunya lebih tua; sebaliknya, bila naskah menyangkut soal kejawaan, maka naskah di daerah lain yang memuat unsur kejawaan merupakan naskah belakangan. ${ }^{38}$ Berikutnya, karya dengan huruf Arab dan Jawi (Arab Melayu). Karya dalam kelompok ini kebanyakan berupa salinan atau turunan dari kitab-kitab yang sudah ada, seperti kitab suci al-Qur'an, Perukunan, Sifat Dua Puluh, Mujarrobat, dan semacamnya.

Di beberapa tempat, naskah-naskah tersebut sangat dihormati dan diperlakukan secara istimewa, layaknya benda yang hidup. Karena perlakuan yang demikian istimewa, tidak setiap orang dapat menyentuhnya, apalagi membacanya. Seperti di Sembalun, sampai sekarang masih terdapat naskahnaskah yang diperkirakan sudah berumur ratusan tahun menurut

${ }^{37}$ Herman et.al., Bunga ..., 9-10.

${ }^{38}$ Ibid. 
pemangkunya, ${ }^{39}$ yaitu kitab tasawuf. Untuk menyentuhnya atau membacanya harus diawali dengan ritual-ritual tertentu, yang apabila tidak dilakukan, maka masyarakat di sekitarnya akan mendapatkan suatu musibah. Sementara itu, di beberapa tempat lain yang mempercayai bahwa naskah-naskah yang sudah berumur ratusan tahun dapat menyembuhkan orang yang sakit. Dalam masyarakat Sasak ada yang dikenal dengan istilah medan, yaitu seseorang yang menderita suatu penyakit dan yang dapat menyembuhkannya adalah bendabenda kuno. Babad-babad termasuk salah satu dari benda kuno yang dipercaya dapat menyembuhkan penyakit yang diderita seseorang. Untuk menyembuhkan penyakit tersebut, biasanya suatu naskah harus dicuci (Sasak: pandik), kemudian air bekas cuciannya digunakan untuk mandi atau diminum oleh yang sakit. Akibat tradisi semacam ini naskah-naskah tersebut sangat rentan terhadap kerusakan dan akan cepat lapuk. Ada juga yang sebaliknya, masyarakat sama sekali tidak memandang naskah-naskah tersebut memiliki arti apa-apa, akibatnya terkadang menyimpannya sembarangan. Masyarakat seperti itu biasanya menyimpan naskah-naskah tersebut di atas pembakaran (di atas tempat memasak) atau diletakkan (diselip) di atap rumah sehingga naskah-naskah dari Lombok kebanyakan berwarna hitam akibat terlalu sering kena asap.

Di pulau Lombok ditemukan tidak kurang dari 2000-an hasil karya intelektual muslim. Sekarang ini yang dikoleksi oleh Museum Negeri NTB lebih dari 1200-an naskah ${ }^{40}$ dan sekitar 800-an yang tersebar di luar pulau Lombok, baik itu yang dikoleksi oleh museum-museum di Nusantara maupun di Luar Negeri, khususnya yang terbanyak adalah di Belanda. Pada waktu penaklukan Lombok oleh Belanda pada tahun 1894-1942, tidak kurang dari 600-an babad atau naskah yang dibawa ke Belanda. Menurut perkiraan, yang dapat dikumpulkan sekarang adalah sepertiga dari jumlah

${ }^{39}$ Pemangku adalah orang yang dipercayai menjaga barang-barang kuno tersebut. Secara umum pemangku adalah orang yang diberikan kewenangan secara penuh terhadap peninggalan-peninggalan kuno, biasanya kewenangan tersebut diperoleh secara turuntemurun.

${ }^{40}$ Jelasnya jumlah naskah yang dikoleksi oleh Museum NTB, lihat katalog yang disusun oleh, Dick van Der Meij, Koleksi Naskah Museum Negeri Nusa Tenggara Barat Berdasarkan Daftar Spesifikasi Naskah Koleksi Museum NTB (1990), 1-24. Katalog yang paling lengkap untuk naskah-naskah dari Lombok adalah disusun oleh Geoffrey E. Marrison, Catalogue of Javanese and Sasak Texts (Leiden: Koninklijk Instituut Voor Taal, Land, en Volkenkunde, 1999). 
babad (naskah) yang ada. Jadi, yang masih tersebar di masyarakat adalah tiga kali lebih banyak dari yang dikoleksi oleh museum-museum tersebut.

\section{Catatan Akhir}

Masyarakat Sasak telah mengenal tulisan sekitar abad VIII-IX M melalui para pedagang dan penguasa dari Jawa dan Bali, sedangkan tradisi tulisnya dimulai pada abad XIV M. Salah satu karya tulis yang tertua adalah manuskrip yang mengabadikan kehadiran Majapahit di Lombok pada pertengahan abad XIV M. Ribuan karya intelektual (manuskrip) yang dihasilkan oleh masyarakat Sasak kebanyakan ditulis pada masa kejayaan kerajaan Islam di Lombok. Aktivitas tradisi tulis naskah masyarakat Sasak berlanjut sampai abad XX M.

Berkembangnya tradisi tulis dalam masyarakat Sasak, selain karena dukungan istana yang memfasilitasi para penulis dan sastrawan, juga karena faktor budaya dan agama. Masyarakat memberikan ruang gerak yang kondusif bagi pengembangan tradisi tulis dan agama, dengan berbagai ragam ajarannya mendukung dan memperkaya khazanah intelektual masyarakat Sasak. 